\title{
空気ばねの特性に絞り特性が及ぼす影響*
}

\author{
山本 浩*1, 鄭穎*1, 奥 本 眞 吾*2
}

\section{Effects of Restriction Characteristics on Characteristics of Air Suspension}

\author{
Hiroshi YAMAMOTO*3, Ying ZHENG and Shingo OKUMOTO
}

\author{
${ }^{* 3}$ Department of Mechanical Engineering, Saitama University, \\ 255 Shimo Ohkubo, Sakura-ku, Saitama-shi, Saitama, 338-8570 Japan
}

\begin{abstract}
In this study we make clear the characteristics of an air suspension with a flow channel connected from a cylinder to a reservoir tank. The flow resistance of channel is given by a viscous restriction or an orifice restriction. Differences between approximated analytical results, which are based on the 3 -element model, of stiffness and damping coefficients of the air suspension with the viscous restriction and results of numerical analysis considering non-linear characteristics are very small. Moreover, the approximated analytical results of a transfer function of the air suspension and the experimental results of it are good well. Dependence of the oscillating amplitude on the maximum value of the transfer function of the air suspension system with the viscous restriction is very small since dependence of the oscillating amplitude on the stiffness and the damping is almost negligible. However, it depends on the oscillating amplitude of air suspension system with the orifice restriction because the damping coefficient of that decreases when the oscillating amplitude decreases. We can choose the optimal restriction coefficient of viscous restriction to minimize resonance amplitude easily. However, it is difficult to choose the optimal restriction coefficient of orifice restriction to minimize resonance amplitude because the oscillating amplitude often fluctuates generally. Thus, the air suspension with the viscous restriction is better for isolating the small vibration, in case of the high precision machinery.
\end{abstract}

Key Words : Vibration Isolation, Damping, Optimum Design, Precision Instrument, Air Suspention, Viscous Restriction, Orifice Restriction

\section{1. 緒言}

現在鉄道車両などにおいて多く用いられている空気 ばねは, ピストンおよびシリンダに相当する部分の他 にシリンダと導通する補助タンクを設けて, ばね体積 を大きくすることにより支持剛性を低くするととも に, シリンダと補助タンクの間の空気流路に設けたオ リフィス部分で与えられる流体抵抗, すなわち絞りに より減衰効果を得る構造となつている ${ }^{(1)}$.このような 構造の空気ばねのばね定数および減衰係数は周波数お よび振幅に依存するものとなるが, 小田・西村 ${ }^{(2)}$ は, 絞 りにおける流量と圧力差の関係が線形であり, 絞りに 起因する空気ばねの減衰係数に振幅依存性がないと考 えられる場合について, 微小振動を仮定することによ り，周波数および振幅によらず係数が一定である等価

\footnotetext{
* 原稿受付 2007 年 9 月 20 日

*1 正員, 埼玉大学大学院理工学研究科(更 338-8570 さいたま 市桜区下大久保 255).

*2 学生員, 東北大学大学院工学研究科(恶980-8579 仙台市青 葉区荒巻字青葉 6-6-01).

E-mail : yamamoto@mech.saitama-u.ac.jp
}

なばねおよび減衰要素を並列結合した Voigt モデルに ばねを直列結合した 3 要素系で空気ばねを近似的にモ デル化できることを明らかにしているが, 系の非線形 性を考慮した厳密な計算結果との比較や実験結果との 比較はなされていない. また小柳 ${ }^{(3)}$ は, 小田・西村の モデルで表しうる空気ばねで質量を支持した系におい て，共振倍率を最小化する設計指針を明らかにすると ともに,オリフィス絞りで減衰を付与する空気ばねに おける減衰係数には振幅依存性があることを実験によ り示し, この問題を解消するため可変絞り機構を提案 している，その他空気ばねの絞りに起因する減衰効果 に関連する研究として, 浅見・関口 ${ }^{(4)}{ }^{(5)}$ は, ピストン とシリンダからなる空気ダンパに関して, ピストンと シリンダの間の狭いすきまにおける粘性に起因する減 衰効果とシリンダに設けたオリフィスに起因する減衰 効果の特徴を理論および実験から明らかにしている. 小柳 ${ }^{(3)}$ の実験結果で示されているとおり，これまで 用いられているオリフィス絞りにより減衰効果を得る 空気ばねにおいては, 微小振幅の振動に対しては減衰 
が著しく小さくなってしまうという問題があり，また 可変絞り機構を用いた場合には構造が複雑になってし まうという問題があるため, いずれの場合も，小型精 密機器などで求められる微小振動を低コストで防振す るという観点からは必ずしも理想的とは言いがたい.

そこで本研究では, シリンダと補助タンクの間の空 気流路を狭いスリット状とした粘性絞り特性を有する 空気ばねと, 広い空気流路に小径の穴を設けたオリ フィス絞り特性を有する空気ばねについて, 絞り特性 が空気ばね支持系の振動特性に及ぼす影響を計算およ び実験により明らかにすることにより粘性絞りを有す る空気ばねの有効性を明らかにするとともに, 粘性絞 りを有する空気ばねに小田・西村のモデルを適用した 場合の妥当性を計算および実験により明らかにしたの で，以下に報告する.

\section{2. 絞りを有する空気ばね}

図 1 に本研究で対象とする流路に絞りを有する補助 タンク付き空気ばねの概念図を示す. シリンダと補助 タンクをつなぐ流路を長さ $l$ および幅 $b$ に比べすきま $h$ が十分に狭いスリット状にすることにより, 毛細管 に比べ低コストで製作可能な形状で粘性が支配的な流 れを実現することができ，この部分の粘性抵抗により 減衰効果を得ることができると考えられる.また流路 を広くし流路入り口に小径の穴を開けた薄板を取り付 けることによりオリフィス絞りを実現することができ， この部分の抵抗により減衰効果を得ることができる. これまでの空気ばねにおいては流路抵抗をオリフィス により与えていたため, 圧力差は空気流速の 2 乗にほ ぼ比例する関係となっており, 結果としてピストンの 移動速度の 2 乗にほぼ比例する減衰力が生じうるもの であった。この場合，ピストン振幅が小さい場合には 減衰力が著しく小さくなってしまうという問題があり, これを解決するべく, 本研究では圧力差が空気流速に ほぼ比例する関係となり, 結果としてピストンの移動 速度に比例する減衰力が生じうる粘性絞りによりシリ ンダと補助タンクを結合する形式の空気ばねについて 主に検討し，此較のためオリフィス絞りを有する場合 についても検討を行った. 以下ピストン断面積を $A$, 初期圧力を $p_{0}$, シリンダ初期体積を $V_{c}$, 補助タンク 体積を $V_{r}$, 全体積を $V=V_{c}+V_{r}$, 体積比を $\eta=V_{r} / V$ とし, 空気ばねに変位 $u$ を与えたときのピストン変位 を $x$, シリンダ圧力の変動成分を $p_{c}$, 補助タンク圧力 の変動成分を $p_{r}$ として解析を行う.

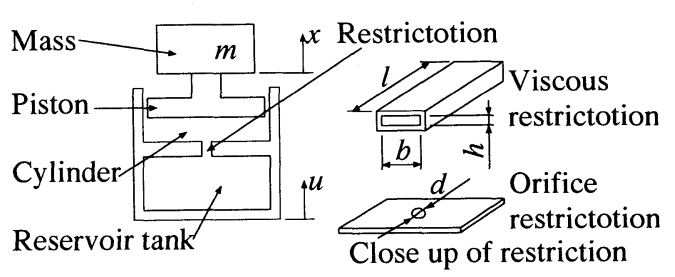

Fig. 1 Concept of air suspention

\section{3. 理 論 解 析}

3.1 補助タンク付き空気ばねの圧カとピストン変 位の関係 はじめに, 空気ばねの基本的な特性を明 らかにするべく, ピストンのシリンダに対する相対変 位 $y=x-u$ と空気ばね圧力との関係を求める. 断熱 変化の場合, シリンダ内の空気の質量変化率 $\Delta m_{c}$ は, シリンダ内の空気の密度を $\varrho_{c}$, 体積を $v_{c}$ とすると,

$$
\Delta m_{c}=\frac{\partial}{\partial t}\left(\varrho_{c} v_{c}\right)=\frac{\partial}{\partial t}\left[\left(\frac{p_{0}+p_{c}}{p_{0}}\right)^{\frac{1}{\gamma}} \varrho_{0}\left(V_{c}+A y\right)\right] \text { (1) }
$$

となる.ここで $\gamma$ および $\varrho_{0}$ はそれぞれ空気の比熱比 および初期状態における密度である. 同様に, 補助夕 ンク内の空気の質量変化率 $\Delta m_{r}$ は, 補助夕ンク内の空 気の密度を $\varrho_{r}$, 体積を $v_{r}$ とすると，

$$
\Delta m_{r}=\frac{\partial}{\partial t}\left(\varrho_{r} v_{r}\right)=\frac{\partial}{\partial t}\left[\left(\frac{p_{0}+p_{r}}{p_{0}}\right)^{\frac{1}{\gamma}} \varrho_{0} V_{r}\right]
$$

となる.

式 (1) および (2) を無次元圧力 $P_{c}=\left(p_{0}+p_{c}\right) / p_{0}$ お よび $P_{r}=\left(p_{0}+p_{r}\right) / p_{0}$, ピストンの無次元変位 $Y=$ $y / y_{0}\left(y_{0}=V / A\right)$ および無次元時間 $\tau=\omega t(\omega$ はピスト ンの運動の角周波数) を用いて整理すると, それぞれ 次式のようになる.

$$
\begin{aligned}
\Delta m_{c} & =\frac{\omega \varrho_{0} V}{\gamma} P_{c}^{\frac{1-\gamma}{\gamma}}\left\{P_{c}^{\prime}(Y+1-\eta)+\gamma P_{c} Y^{\prime}\right\} \\
\Delta m_{r} & =\frac{\omega \varrho_{0} V \eta}{\gamma} P_{r}^{\frac{1-\gamma}{\gamma}} P_{r}^{\prime}
\end{aligned}
$$

ここで, 記号” ’ " は諸量の無次元時間 $\tau$ による微分を 表す.シリンダから補助タンクへの流路を通る空気の 質量流量は, 流路をスリットとし粘性流れと仮定でき る場合は

$$
q_{v}=\frac{\varrho_{0} b h^{3}}{12 \mu l}\left(p_{c}-p_{r}\right)=\frac{\varrho_{0} p_{0}}{Z}\left(P_{c}-P_{r}\right)
$$


となる.ここで $\mu$ は空気の粘度, $b, h, l$ はそれぞれ スリット状流路の幅, すきま, 長さである. また,

$$
Z=\frac{12 \mu l}{b h^{3}}
$$

で表される $Z$ は絞りの抵抗係数であり, 式 (4) より $Z$ が大きいほど流量 $q_{v}$ が少なく, すなわち流路の抵抗 が大きくなることがわかる．そして，粘性絞りの場合 には式 (4) よりシリンダと補助タンクの圧力差 $p_{c}-p_{r}$ は質量流量 $q_{v}$ に比例することがわかる。一方, 流路 がオリフィスと仮定できる場合の空気の質量流量は

$$
\begin{aligned}
q_{o} & =C_{D} S \operatorname{sgn}\left(p_{c}-p_{r}\right) \sqrt{2 \varrho_{0}\left|p_{c}-p_{r}\right|} \\
& =C_{D} S \operatorname{sgn}\left(P_{c}-P_{r}\right) \sqrt{2 \varrho_{0} p_{0}\left|P_{c}-P_{r}\right|}
\end{aligned}
$$

となる.ここで $C_{D}$ はオリフィスの流量係数で $S$ はオリ フィスの断面積である. そして, オリフィス絞りの場合 には式 (6) よりシリンダと補助タンクの圧力差 $p_{c}-p_{r}$ は質量流量 $q_{o}$ の 2 乗に比例することがわかる.

シリンダおよび補助タンク内の気体の無次元質量変 化率を次のように定義する.

$$
\begin{aligned}
& \Delta M_{c}=\frac{\gamma}{\omega \varrho_{0} V} \Delta m_{c}=P_{c}^{\frac{1-\gamma}{\gamma}}\left\{P_{c}^{\prime}(Y+1-\eta)+\gamma P_{c} Y^{\prime}\right\} \\
& \Delta M_{r}=\frac{\gamma}{\omega \varrho_{0} V} \Delta m_{r}=\eta P_{r}^{\frac{1-\gamma}{\gamma}} P_{r}^{\prime}
\end{aligned}
$$

粘性絞りおよびオリフィス絞りにおける無次元質量流 量 $Q_{v}$ および $Q_{o}$ はそれぞれ以下のとおりである.

$$
\begin{aligned}
& Q_{v}=\frac{\gamma}{\omega \varrho_{0} V} q_{\nu}=\frac{1}{\sigma_{v}}\left(P_{c}-P_{r}\right) \\
& Q_{o}=\frac{\gamma}{\omega \varrho_{0} V} q_{o}=\frac{1}{\sigma_{o}} \sqrt{\left|P_{c}-P_{r}\right|} \operatorname{sgn}\left(P_{c}-P_{r}\right)
\end{aligned}
$$

ここで $\sigma_{\nu}=\omega V Z / \gamma p_{0}$ および $\sigma_{o}=\omega V / \gamma C_{D} S \sqrt{2 p_{0} / \varrho_{0}}$ はそ扎ぞれ粘性絞りおよびオリフィス絞りの場合の無 次元周波数である.

質量保存則 $\Delta M_{c}=-Q$ および $\Delta M_{r}=Q$ より

$$
\begin{aligned}
& P_{c}^{\frac{1-\gamma}{\gamma}}\left\{P_{c}^{\prime}(Y+1-\eta)+\gamma P_{c} Y^{\prime}\right\}+Q=0 \\
& P_{r}^{\frac{1-\gamma}{\gamma}} P_{r}^{\prime}-Q=0
\end{aligned}
$$

が得られ， $Y$ および $Y^{\prime}$ をえることにより $P_{c}$ および $P_{r}$ を求めることができる.ここで $Q$ は絞りにおける 無次元質量流量で, 粘性絞りの場合は $Q_{v}$ を, また才 リフィス絞りの場合は $Q_{o}$ を用いる. 式 (9) は $P_{c}$ およ び $P_{r}$ に関して非線形なので,

$$
\begin{aligned}
& P_{c}^{\prime}=-\frac{1}{Y+1-\eta}\left(\gamma P_{c} Y^{\prime}+P_{c}^{\frac{\gamma-1}{\gamma}} Q\right) \\
& P_{r}^{\prime}=\frac{1}{\eta} P_{r}^{\frac{\gamma-1}{\gamma}} Q
\end{aligned}
$$

のように変形しルンゲ・クッタ法などにより数值的に 解くか, 後述のように摄動法により $Y$ の微小変動に対 する $P_{c}$ および $P_{r}$ の微小変動量を求める.

式 (10) に $Y=Y_{0} \sin \tau$ および $Y^{\prime}=Y_{0} \cos \tau$ を与え数 值的に解いて得られる $P_{c}$ の時刻歴応答より, 次式に より無次元剛性 $K$ および減衰 $C$ を求める.

$$
\begin{aligned}
& K=\frac{1}{\pi} \int_{0}^{2 \pi} \frac{P_{c}}{Y_{0}} \sin \tau d \tau \quad\left(=\frac{V}{A^{2} p_{0}} \cdot k\right) \\
& C=\frac{1}{\pi} \int_{0}^{2 \pi} \frac{P_{c}}{Y_{0}} \cos \tau d \tau \quad\left(=\frac{V}{A^{2} p_{0}} \cdot c \omega\right)
\end{aligned}
$$

ここで $Y_{0}$ はピストンの無次元相対振幅である. また $k$ および $c$ はそれぞれ有次元のばね定数および減衰係 数である.

3.2 摃動法による特性解析絞りにおける無次 元質量流量 $Q$ が $\left(P_{c}-P_{r}\right) / \sigma$ と表せる場合には, 質量 保存則 $\Delta M_{c}=-Q$ および $\Delta M_{r}=Q$ より

$$
\begin{aligned}
& P_{c}^{\frac{1-\gamma}{\gamma}}\left\{P_{c}^{\prime}(Y+1-\eta)+\gamma P_{c} Y^{\prime}\right\}+\frac{1}{\sigma}\left(P_{c}-P_{r}\right)=0 \\
& P_{r}^{\frac{1-\gamma}{\gamma}} P_{r}^{\prime}-\frac{1}{\sigma}\left(P_{c}-P_{r}\right)=0
\end{aligned}
$$

となる. 無次元圧力および変位をそれぞれ $P_{c}=1+$ $\Delta P_{c} e^{j \tau}, P_{r}=1+\Delta P_{r} e^{j \tau}, Y=\Delta Y e^{j \tau}$ のように定常成分 と微小変動成分の和と置いて式 (10)に代入し, 高次の 微小量を無視して整理すると以下のようになる.

$$
\begin{aligned}
& j\left\{(1-\eta) \Delta P_{c}+\gamma \Delta Y\right\}+\frac{1}{\sigma}\left(\Delta P_{c}-\Delta P_{r}\right)=0 \\
& j \eta \Delta P_{r}-\frac{1}{\sigma}\left(\Delta P_{c}-\Delta P_{r}\right)=0
\end{aligned}
$$

上式を $\Delta P_{c} / \Delta Y$ について解くと次式を得る.

$$
\frac{\Delta P_{c}}{\Delta Y}=-\gamma \frac{1+j \eta \sigma}{1+j \eta(1-\eta) \sigma}
$$

式 (14) よりピストンに作用する変動力 $\Delta f\left(=A p_{0} \cdot \Delta P_{c}\right)$ と変位 $\Delta y\left(=y_{0} \cdot \Delta Y\right)$ の関係を表す以下の式が得られる.

$$
\frac{\Delta f}{\Delta y}=\frac{A^{2} p_{0}}{V} \frac{\Delta P_{c}}{\Delta Y}=-\gamma \frac{A^{2} p_{0}}{V} \frac{1+j \eta \sigma}{1+j \eta(1-\eta) \sigma}
$$

また, 式 (11) に対応する無次元剛性 $K$ および減衰 $C$ は以下のようになる.

$$
\begin{aligned}
& K=\operatorname{Re}\left(\frac{\Delta P_{c}}{\Delta Y}\right)=\gamma \frac{1+\eta^{2}(1-\eta) \sigma^{2}}{1+\eta^{2}(1-\eta)^{2} \sigma^{2}} \\
& C=\operatorname{Im}\left(\frac{\Delta P_{c}}{\Delta Y}\right)=\gamma \frac{\eta^{2} \sigma}{1+\eta^{2}(1-\eta)^{2} \sigma^{2}}
\end{aligned}
$$

粘性絞りの場合には式 $(8)$ より $Q=Q_{v}=\left(1 / \sigma_{v}\right)$. $\left(\Delta P_{c}-\Delta P_{v}\right) \cdot e^{j \tau}$ となるので, 式 (13) (16) において $\sigma$ を $\sigma_{v}$ と置き換えれば良い。 また，オリフィス絞りの 


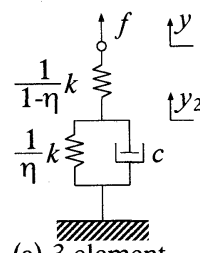

(a) 3 element

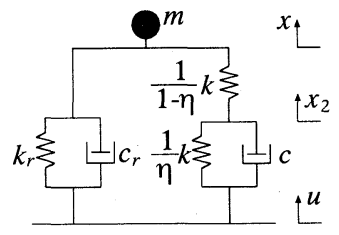

(b) 3 element with rubber
Fig. 2 Dynamical model of air suspension

場合も, $P_{c}-P_{r}$ が調和関数で表されるとき $Q_{o} も$ 同周 期で同位相の調和関数で表されると仮定すると,

$$
\begin{aligned}
& \operatorname{sgn}(\sin \tau) \sqrt{|\sin \tau|} \approx a \sin \tau \\
& a=\frac{1}{\pi} \int_{0}^{2 \pi}\{\operatorname{sgn}(\sin \tau) \sqrt{|\sin \tau|}\} \sin \tau d \tau
\end{aligned}
$$

の関係を用いることにより, $P_{c}=1+\Delta P_{c} e^{j \tau}, P_{r}=$ $1+\Delta P_{r} e^{j \tau}$ とすると

$$
Q_{o}=\frac{a}{\sigma_{o} \sqrt{\left|\Delta P_{c}-\Delta P_{r}\right|}}\left(\Delta P_{c}-\Delta P_{r}\right) \cdot e^{j \tau}
$$

と表すことができるので, 式 (13)〜(16) の $\sigma$ を $\left(\sqrt{\left|\Delta P_{c}-\Delta P_{r}\right|} / a\right) \sigma_{o}$ に置き換えれば良い.このように, オリフィス絞りにおいては $\sigma$ は $\sqrt{\left|\Delta P_{c}-\Delta P_{r}\right|}$ を含む 形となり， $\sigma_{o}$ が一定であっても振幅 $Y_{0}(=|\Delta Y|)$ が大 きくなるほど $\sqrt{\left|\Delta P_{c}-\Delta P_{r}\right|}$ は大きくなり結果として $\sigma$ が大きくなることから， $K$ および $C$ は振幅に依存す ることがわかる.

$3 \cdot 33$ 要素系における变位と反力の関係 図 2(a) に示すばねとダンパを並列に結合した Voigt 要素にさ らにばねを直列に結合した 3 要素系の力の釣合いを考 えると，

$$
\begin{aligned}
& f=\frac{k}{1-\eta}\left(y-y_{2}\right) \\
& 0=-\frac{k}{1-\eta}\left(y_{2}-y\right)-\frac{k}{\eta} y_{2}-c \dot{y_{2}}
\end{aligned}
$$

となる. $y=\Delta y e^{j \omega t}, y_{2}=\Delta y_{2} e^{j \omega t}$ および $f=\Delta f e^{j \omega t}$ とおき, 式 (19) に代入し $\Delta f / \Delta y$ について解くと,

$$
\frac{\Delta f}{\Delta y}=-k \frac{1+j \omega \eta(c / k)}{1+j \omega \eta(1-\eta)(c / k)}
$$

となる.ここで

$$
k=\gamma \frac{A^{2} p_{0}}{V}, \sigma=\frac{c}{k} \omega
$$

とおくと式 (20) は式 (15) となることから, $Q=\left(P_{c}-\right.$ $\left.P_{r}\right) / \sigma$ と表せる場合のように, 絞り流量が圧力差に比 例する空気ばねは 3 要素系と等価であることがわかる. 式 (20) を係数のとり方や無次元化の方法を変えるこ
とにより小田・西村 ${ }^{(2)}$ あるいは小柳 ${ }^{(3)}$ の示す式と同様 の形となる. 粘性絞りの場合は $c=A^{2} Z$ となり等価な 減衰係数 $c$ は振幅に依存しないが, オリフィス絞りの 場合には $c=A^{2} \sqrt{\left(\left|\Delta P_{c}-\Delta P_{r}\right| / a^{2} C_{D}{ }^{2} S^{2}\right) \cdot\left(\varrho_{0} / 2 p_{0}\right)}$ と なるので, 3 要素系にモデル化した場合でも等価な減 衰係数 $c$ は圧力差に, すなわち振幅に依存することに なる.

3.4 空気ばね支持系の伝達関数 節 3.3 に示し たとおり粘性絞りを有する空気ばねは 3 要素系と等価 であることから, 粘性絞りを有する空気ばねで支持さ れた質量の変位の基礎の変位に対する伝澾関数は 3 要 素系のそれと同等となる. 実際の空気ばねにおいては, ピストンとシリンダの気密性を高めるためゴム膜を用 いることが多いので, ここでは図 2(b)に示す, 3 要素 系にゴム膜に対応する等価剛性 $k_{r}$ と等価隇衰 $c_{r}$ を並 列に配置した系について考える. 系の運動方程式は

$$
\begin{aligned}
& m \ddot{x}+\frac{k}{1-\eta}\left(x-x_{2}\right)+c_{r}(\dot{x}-\dot{u})+k_{r}(x-u)=0 \\
& \frac{k}{1-\eta}\left(x_{2}-x\right)+\frac{k}{\eta}\left(x_{2}-u\right)+c\left(\dot{x_{2}}-\dot{u}\right)=0
\end{aligned}
$$

となる. $x=X e^{j \omega t}, x_{2}=X_{2} e^{j \omega t}$ および $u=U e^{j \omega t}$ を式 (22) に代入し $X / U$ について解き, 整理すると,

$$
\begin{aligned}
& H=\frac{X}{U}=\frac{B+j \omega D}{E+j \omega G} \\
& B=k+k_{r}-\omega^{2} \eta(1-\eta) c_{r} \frac{c}{k} \\
& D=\eta(1-\eta) k_{r} \frac{c}{k}+\eta c+c_{r} \\
& E=k+k_{r}-\omega^{2}\left\{m+\eta(1-\eta) c_{r}\right\} \frac{c}{k} \\
& G=\eta(1-\eta)\left(k_{r}-m \omega^{2}\right) \frac{c}{k}+\eta c+c_{r}
\end{aligned}
$$

となる，以下，粘性絞りを有する空気ばねについて， 式 (23) を用いた計算結果を実験結果と比較検討する ことにより, 計算手法の妥当性を検証する.

\section{4. 実験装置および実験方法}

\section{$4 \cdot 1$ 実験装置図 3 に試作空気ばねの構造概略} を示す. 本実験装置では, 空気ばねの上下方向運動に 関する特性を明らかにすることを目的とし, 多少構造 は複雑となるが, 傾き運動を避けるようにピストンを 直動形ころがりガイドにより支持する構造としている. そして, ピストンはシリンダに対しゴム膜を介して取 り付けられており, ゴム膜の外周部分はU 字断面と なっている.このような構造にすることにより, 空気 の圧縮膨張に対する膜そのものの伸縮量を小さくしな がら, ピストンの可動方向の剛性を極力低くすること ができ，ゴム膜の影響を低減することができる．また シリンダを空気ばね中央部に配置し，その外側部分全 周に補助タンクを配置する構造となっており, シリン 


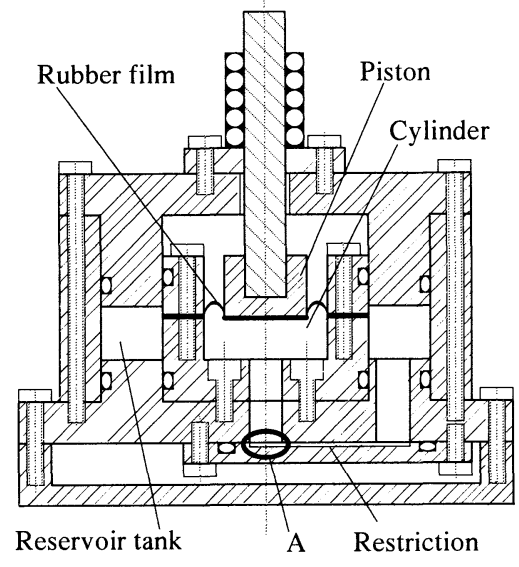

Fig. 3 Configuration of air suspention

Table 1 Experimental conditions

\begin{tabular}{||l|l||l|l||}
\hline$A$ & $3.14 \times 10^{-4}\left(\mathrm{~m}^{2}\right)$ & $m$ & $0.08(\mathrm{~kg})$ \\
\hline$V$ & $4.49 \times 10^{-5}\left(\mathrm{~m}^{3}\right)$ & $\eta$ & 0.909 \\
\hline$b$ & $8(\mathrm{~mm})$ & $l$ & $23(\mathrm{~mm})$ \\
\hline$k_{r}$ & $1.70 \times 10^{3}(\mathrm{~N} / \mathrm{m})$ & $c_{r}$ & $2.16(\mathrm{~N} / \mathrm{m} / \mathrm{s})$ \\
\hline$h$ & $0.0,0.1,0.2,0.4,3.0(\mathrm{~mm})$ \\
\hline$d$ & $0.7,0.8(\mathrm{~mm})$ \\
\hline
\end{tabular}

ダ下部と補助タンク下部が流路でつながれている。こ の部分を狭いスリットにすることにより, 粘性絞りを 実現することができ，またこの部分を広い流路とし， 図中 A で示すシリンダ部分の流路入り口に小径の穴 を開けた厚さ $0.1 \mathrm{~mm}$ の薄板を取り付けることにより， オリフィス絞りを実現することができる.

4.2 実験方法 図 4 に伝達関数測定系概略を示 す. 空気ばね本体を電磁式加振機にて振幅一定で正弦 加振し, 周波数を変化させて空気ばね本体の変位と空 気ばねのピストンの変位をレーザ変位計により測定し, 両者より伝達関数を算出する. また絞り特性の振幅依 存性を明らかにするため, 加振振幅を変化させ伝達関 数の測定を行った.

表 1 に実験条件を示す. $h=0.0 \mathrm{~mm}$ は絞りをふさい だ場合に対応し, $h=3.0 \mathrm{~mm}$ は絞りにおける抵抗が無 視できる場合に対応する.ゴム膜の等価剛性 $k_{r}$ およ び等価減衰 $c_{r}$ は, 図 3 に示す絞りを構成する部材を 取り外し, 空気ばねを開放し作動しない状態にして測 定した伝達関数より求めた.
FFT Laser displacement sensor

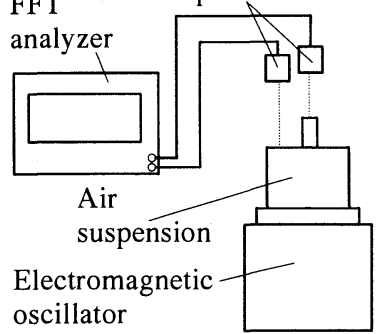

Fig. 4 Experimental apparatus

\section{5. 結果}

5.1 数值解析結果 図 5 に, 粘性絞りを用いた 場合について, ルンゲ・クッ夕法による数值解析によ り求めた無次元剛性 $K$ および無次元減衰 $C$ と無次元 周波数 $\sigma_{v}$ との関係を, ピストンの無次元振幅 $Y_{0}$ をパ ラメータとして体積比 $\eta=0.9$ とした場合について示 す. 図 5 に示すとおり, 剛性および減衰の周波数特性 はほとんど振幅に依存しないことがわかる.

また, 摂動法により求めた剛性 $K_{p}$ および減衰 $C_{p}$ の 妥当性を明らかにするべく, 数值解析で求めた剛性 $K_{n}$ および減衰 $C_{n}$ と比較する. 図 6 に 2 つの方法で求め た剛性および減衰の相対誤差 $K_{\text {error }}=\left(K_{p}-K_{n}\right) / K_{n}$ お よび $C_{\text {error }}=\left(C_{p}-C_{n}\right) / C_{n}$ と $\sigma_{v}$ との関係を $Y_{0}$ をパラ メータとして体積比 $\eta=0.9$ とした場合について示す. 図6に示すとおり， $Y_{0}$ が大きくなるほど誤差は大きく なるが, $Y_{0}=0.02$ の場合でも, 実用上問題となる無次 元減衰 $C$ が最大となる $\sigma_{v}=10$ 近傍で $C_{\text {error }}=1 \%$ 程 度であり, 摂動法による解析でも実用上十分であると いえる。

図 7 にオリフィス絞りを用いた場合について, ルン ゲ・クッ夕法による数值解析により求めた $K$ および $C$ と $\sigma_{o}$ との関係を $Y_{0}$ をパラメータとして体積比 $\eta=0.9$ とした場合について示す. 剛性および減衰の周波数特 性は, いずれの $Y_{0}$ の場合も $K$ に関しては $\sigma_{o}$ が大きく なるほど単調に増加しある值に漸近し,$C$ に関しては ある $\sigma_{o}$ の值で極大となりその後減少するという, 図 6 に示す粘性絞りを用いた場合と類似の傾向を有する ことがわかる.このことは図 5 および図 7 における $Y_{0}=0.001$ の場合の結果を比較するとほぼ同様である ことからも理解できる.このように粘性絞りを用いた 場合とオリフィス絞りを用いた場合が類似の傾向を有 することが, これまでの入力振幅が一定とした場合に 関する研究では $Q \propto\left(P_{c}-P_{r}\right)$ と考えても空気ばねの特 性をかなり良く表しうるとされていた理由であると考 


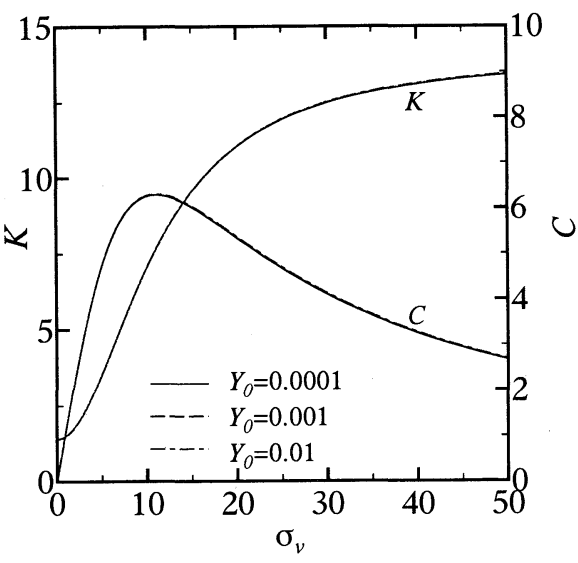

Fig. 5 Relations of dimensionless stiffness $K$, dimensionless damping $C$ and dimensionless frequency $\sigma_{v}$ (Viscous restriction, $\eta=0.9$ )

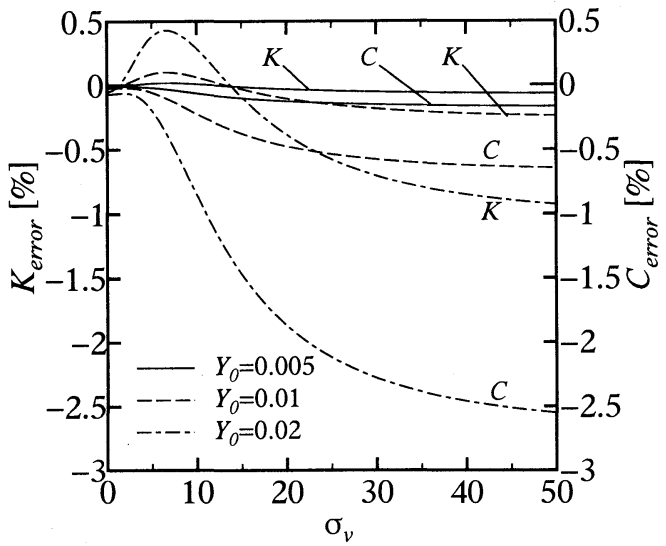

Fig. 6 Relations of dimensionless stiffness error $K_{\text {error }}$, dimensionless damping error $C_{\text {error }}$ and dimensionless frequency $\sigma_{v}$ (Viscous restriction, $\eta=0.9$ )

えられる.しかし図 7 に示すように， $Y_{0}$ が小さい場合 ほど $C$ が最大となる $\sigma_{o}$ は高くなるなど, 明らかにそ の特性は振幅に依存していることから，オリフィス絞 りを用いた空気ばねにおいて外乱の振幅が変動する場 合には，入力振幅を一定として設計した時に意図した 最適な特性は必ずしも得られないといえる。

5.2 粘性絞りを有する空気ばねの特性図 8 に, 粘性絞りを用いたときの, 基礎励振変位と支持質量変 位, すなわち空気ばね本体の変位に対するピストン変 位の関係を表す伝達関数の摂動法による近似計算結果

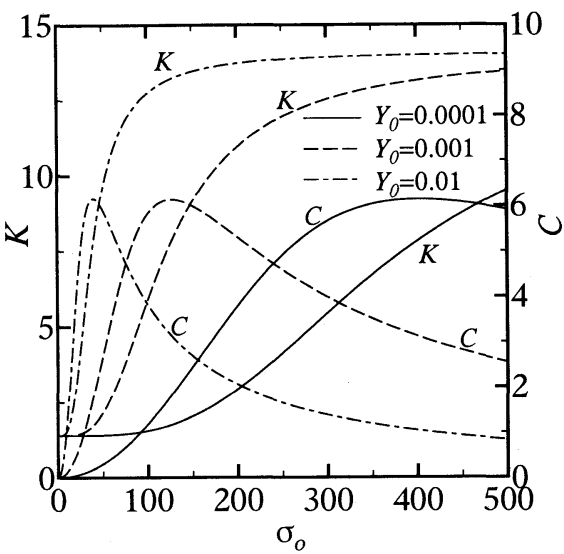

Fig. 7 Relations of dimensionless stiffness $K$, dimensionless damping $C$ and dimensionless frequency $\sigma_{o}$ (Orifice restriction, $\eta=0.9$ )

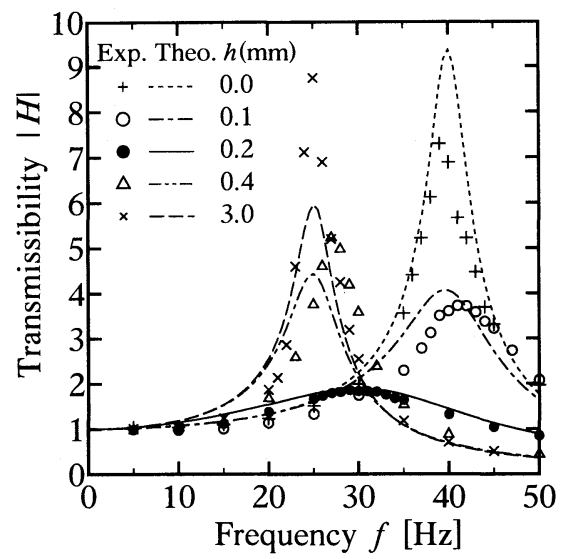

Fig. 8 Relation between transmissibility $|H|$ and frequency $f$ (Viscous restriction, $u_{0}=0.07 \mathrm{~mm}$ )

と実験結果を, 絞りスリットすきま $h$ をパラメータと して示す.ここで基礎の励振振幅 $u_{0}$ は一定值 $0.07 \mathrm{~mm}$ とした. $h=0.2 \mathrm{~mm}$ は計算結果において共振倍率が最 小となる場合であるが, 実験結果においても共振倍率 は非常に小さくなっている，またこれに関連して $h$ が $0.2 \mathrm{~mm}$ 以下の場合は $h$ が小さくなるにつれて, $h$ が $0.2 \mathrm{~mm}$ 以上の場合は $h$ が大きくなるにつれて共振倍率 は大きくなることがわかる.さらに $h$ が $0.2 \mathrm{~mm}$ 以上 の場合は $h$ が大きくなるにつれ共振振動数は $25 \mathrm{~Hz}$ に 漸近するが, これはこの領域においては流路の粘性抵 抗がさほど大きくないため, 流路を通じたシリンダと 補助夕ンクの空気の流入出が十分にあり, その結果空 


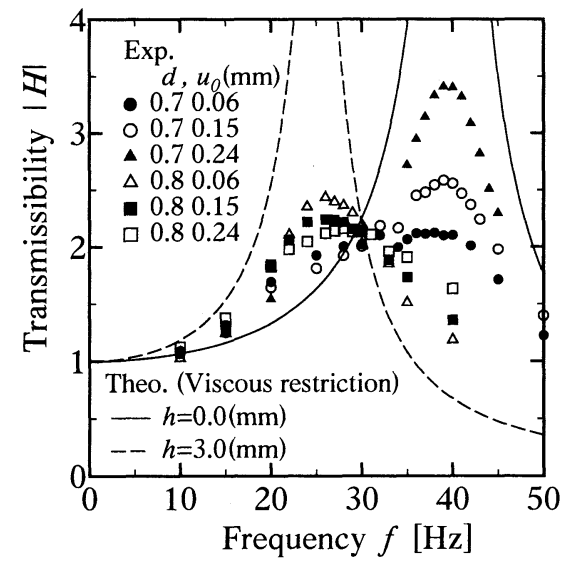

Fig. 9 Relation between transmissibility $|H|$ and frequency $f$ (Orifice restriction)

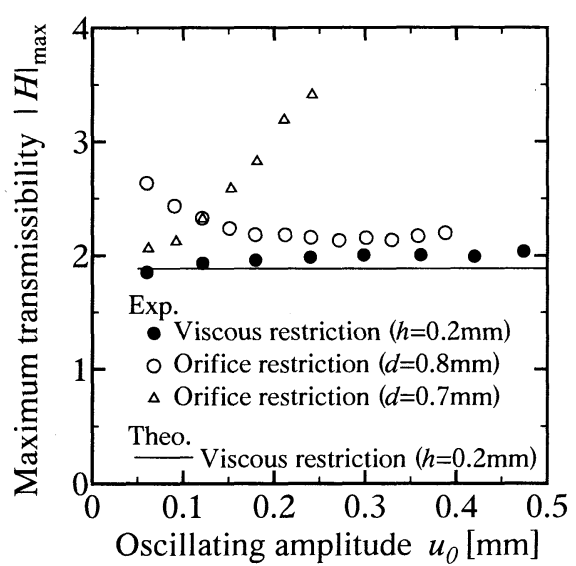

Fig. 10 Relation between maximum transmissibility $|H|_{\text {max }}$ and oscillating amplitude $u_{0}$

気ばねの剛性は, $h$ が大きくなるにつれて絞り抵抗が 無視できる $h$ が $3 \mathrm{~mm}$ の場合の值に，すなわちシリン ダと補助タンクをあわせた体積により決まる值に漸近 するためである。一方 $h$ が $0.2 \mathrm{~mm}$ より小さい領域に おいては共振振動数は $40 \mathrm{~Hz}$ に漸近しているが, これ はこの領域においては流路の粘性抵抗が大きいため, 流路を通じたシリンダと補助タンクの空気の流入出は 非常に少なくなり, その結果空気ばねの剛性は, $h$ が 小さくなるにつれて絞りがふさがれた状態である $h$ が $0 \mathrm{~mm}$ の場合の值に, すなわちシリンダのみの体積に より決まる值に漸近するためである。図に示す計算結
果は, シリンダおよび補助タンクと両者をつなぐ粘性 絞り部分により構成される空気ばね自体の特性とゴム 膜の特性をともに考慮した式 (23)により求めたもの であるが, 空気ばねの校りに起因する減衰特性の影響 が支配的となる, 共振倍率を最小化するという観点で の最適条件である $h=0.2 \mathrm{~mm}$ の場合については, 共 振倍率の計算結果は 1.89 であるのに対し実験結果は 1.85 でありよく一致している. またゴム膜の特性がか なり大きな影響を及ぼす共振振幅が大きい場合におい ても計算結果と実験結果はかなりよく一致しているこ とから, 本研究で用いた粘性校りを有する空気ばねを 3 要素系でモデル化し伝達関数を求める解析手法は妥 当であるといえる.

$5 \cdot 3$ オリフィス絞りを有する空気ばねの特性 図 9 にオリフィス絞りを有する空気ばねにおける伝達関 数を, 絞り径 $d$ と基礎励振振幅 $u_{0}$ をパラメータとし て示す. $d$ が $0.7 \mathrm{~mm}$ の場合は最適值に比べ絞り抵抗 が大きい場合に対応し, この場合は $u_{0}$ が大きくなる につれてシリンダと補助タンクの圧力差も大きくなる ので, 絞り抵抗はより大きくなり, 結果として粘性絞 りの場合において最適值より絞り抵抗が大きい場合と 同様に共振倍率は大きくなり, 図中実線で示す, $h$ が $0 \mathrm{~mm}$ の場合の計算結果, すなわち補助タンクがない場 合に相当する結果に漸近する. また $d$ が $0.8 \mathrm{~mm}$ の場 合は最適值に比べ较り抵抗が小さい場合に対応し, こ の場合は $u_{0}$ が小さくなるにつれてシリンダと補助夕 ンクの圧力差も小さくなるので, 絞り抵抗はより小さ くなり, 結果として粘性絞りの場合において最適值よ り絞り抵抗が小さい場合と同様に共振倍率は大きくな り, 図中点線で示す $h$ が $3 \mathrm{~mm}$ の場合の計算結果, す なわちシリンダと補助タンクとの間の流路の抵抗がほ とんどない場合の結果に漸近する。

5.4 伝達率の線形性 図 10 に, 粘性絞りおよび オリフィス絞りを有する空気ばねについて, 伝達関数 の最大值 $|H|_{\max }$ と基礎の励振振幅 $u_{0}$ の関係を示す. 粘 性絞りを有する空気ばねにおいては, $u_{0}$ が変化しても $|H|_{\max }$ はほぼ一定であり，また図中に示す計算結果と かなり良く一致していることから, 微小振動を含む広 い範囲の振幅の外乱振動に対しても有効に振動を絶縁 できる空気ばねを実現できることがわかる．一方，才 リフィス絞りを有する空気ばねにおいては $d=0.8 \mathrm{~mm}$ のときは $u_{0}$ が大きくなるほど $|H|_{\text {max }}$ は小さくなり, また $d=0.7 \mathrm{~mm}$ のときは $u_{0}$ が大きくなるほど $|H|_{\text {max }}$ は大きくなるように, $|H|_{\text {max }}$ は $u_{0}$ に依存することが わかる．このように，オリフィス絞りを用いた場合, ある外乱振動に対して最適な絞り形状であったとして 
も，外乱振動振幅が変化した場合必ずしも最適とはな らず, このことから,オリフィス絞りを有する空気ば ねは外乱振動の振幅が変動する場合必ずしも有効に振 動を絶縁できないことがわかる.

\section{6. 結 言}

本研究では, 微小振幅の低コストでの防振を目的と し，粘性校りを有する空気ばね拉よびオリフィス絞り を有する空気ばねについて, 数值解析, 摂動法による 近似解析，実験によりその特性を明らかにした。本研 究で得られた結論は以下のとおりである.

(1)系の非線形性を考慮した計算より, 粘性絞りを有 する空気ばねの剛性および隇衰の周波数特性は, ピス トン振幅にほとんど依存せずほぼ等しくなることを明 らかにした．またオリフィス絞りを有する空気ばねの 剛性扰よび減衰の周波数特性は, ピストン振幅が一定 の条件下では, それぞれの場合について粘性絞りを有 する空気ばねと類似の傾向を有するが，振幅が大きく なるほど減衰が最大となる周波数は低くなるように， その特徵は振幅に依存することを明らかにした。

(2)粘性絞りおよびオリフィス絞りを有する空気ばね を用いた実験結果より，粘性絞りを有する空気ばね支 持系の共振倍率は基礎の励振振幅に依存しないが，オ リフィス絞りを有する系の共振倍率は励振振幅に依存 し, 励振振幅が大きくなるほど共振倍率が大きくなる 場合と小さくなる場合があることを明らかにした。

(3)粘性絞りを有する空気ばねを 3 要素系にモデル化 した摂動法による計算結果と, 非線形性を考慮した計 算結果との誤差は，振幅が大きくなるほど若干大きく
なるが，実用上問題となる無次元減衰が最大となる無 次元周波数 10 近傍で, 無次元振幅 0.02 のときに無次 元滅衰の誤差は $1 \%$ 程度であり，また，空気ばね支持 系の伝達率の摄動法による計算結果と実験結果は, 変 位励振振幅によらずかなりよく一致することから，摂 動法による計算により粘性絞りを有する空気ばねの特 性を十分よく表しうるといえる。

以上より，粘性絞りを有する空気ばねを用いること により, 外乱振動振幅が変動する場合においても, 微 小振動を低いコストで防振することができるといえる.

\section{文献}

(1) Matsudaira, T., Air Spring for Vehicles, Journal of the Japan Society of Mechanical Engineers, Vol.60, No.464 (1957), pp.908-915.

(2) Oda, N. and Nishimura, S., Vibration of Air Suspension Vehicles and their Design, Journal of the Japan Society of Mechanical Engineers, Vol.35, No.273 (1969), pp.9961002.

(3) Koyanagi, S., Optimum Design Methods of Air Spring Suspension Systems, Transaction of the Japan Society of Mechanical Engineers, Series C, Vol.49, No.439 (1983), pp.410-415.

(4) Asami, T. and Sekiguchi, H., Fundamental Investigation on Air Damper(1st Report, Theoretical Analysis), Transaction of the Japan Society of Mechanical Engineers, Series $C$, Vol.56, No.526 (1990), pp.1400-1407.

(5) Asami, T. and Sekiguchi, H., Fundamental Investigation on Air Damper(2nd Report, Theoretical and Experimental Study), Transaction of the Japan Society of Mechanical Engineers, Series C, Vol.56, No.532 (1990), pp.32013209. 